\title{
Impact of Border Strip and Flood Method of Irrigation on Wheat Cultivation in the Malaprabha Command Area of Karnataka
}

\author{
SHREESHAIL RUDRAPUR \\ Ph.D Scholar, Department of Agricultural Economics, \\ B. L. PATIL \\ Professor, Department of Agricultural Economics \\ University of Agricultural Sciences, Dharwad-580005, Karnataka
}

Received: December 25, 2014

doi:10.5296/jas.v3i2.7939
Accepted: January 7, 2015.

URL: http://dx.doi.org/10.5296/ jas.v3i2.7939

\begin{abstract}
A study conducted in the Malaprabha command area revealed that border strip method of irrigation was found better in terms of yield, income and water savings in cultivation of wheat. The crop yield was higher in border strip method of irrigation ( $28.50 \mathrm{q} / \mathrm{ha}$ ) over flood (20.90 q/ha). The net returns was also higher in border strip method of irrigation (Rs. 20851.01/ha) over flood (Rs. 8024.92/ha). The highest cost of irrigation was found in flood method of irrigation (Rs. 2898.47/ha) compared to border strip method of irrigation (Rs. 2051.13/ha). The highest water consumption was seen under flood method of irrigation $(12.04 \mathrm{ha} \mathrm{cm})$ followed by border strip method of irrigation $(8.41 \mathrm{ha} \mathrm{cm})$.
\end{abstract}

Keywords: Border strip method of irrigation, cost of irrigation, flood irrigation, income, water savings, Wheat, yield

\section{Introduction}

Land and water are the basic resources for progress in agriculture and economic development of the country. The demand for these two resources has been continuously increasing, since the Country's population is also on rise since five decades, growing population needs to be fed. Hence scientists have already assessed that the water is going to be a major natural critical resource constraint in enhancing the agricultural production.

Malaprabha command comprises the area of a dam across the river Malaprabha, near 
Navilutheertha in Belgaum district to provide irrigation to an extent of 2,20,028 hectares in Belgaum, Bagalkot, Gadag, and Dharwad districts. Potential created up to the end of May 2010 was 2,13,537 hectares. Cumulative financial and physical progress upto the end of March 2011 were Rs. 1172.36 crores and 2, 13,537 ha respectively. There are two different water management practices being practiced by peasants in cultivation of wheat in the Malaprabha command area, such as flood and border strip method of irrigation. Out of them first one is traditional and other is scientific. Flood irrigation is an ancient method of irrigation and has so many problems with respect to water loss and yield reduction. Thus to overcome the problems of traditional water management practices, the adoption of scientific water management (border strip method of irrigation) practice gains greater attention.

Wheat is a world's number one cereal in area. Wheat is a crop highly responds to irrigation. Hence the water should be applied optimally through scientific irrigation methods. The water use should aim at securing the maximum crop production per unit of water and sustaining soil health. Thus the present paper aims to analyse the impact of scientific water management practice in the cultivation of maize over the traditional water management practice.

\section{Research Methodology}

The present study was conducted in Malaprabha Command Area of Karnataka. Hebsur, Kumargoppa, Kanakikoppa, Guralikatti, Hunasikatti, Mugnur and Naragund villages of Malaprabha command area were purposively selected since the interventions on scientific water management practices were implemented in these villages under RKVY project.

The major traditional irrigation method followed by the farmers in the cultivation of wheat in the study area was flood method whereas; scientific method was border strip method of irrigation which was recommended by the project officials. Thus from each village five farmers practicing each methods were selected randomly, thus the total sample size was 70 and method wise sample size was 35 .

Budgeting technique was followed for estimating the cost, returns, water savings, profits of crop grown in various water management practices and average income from wheat crop.

\section{Results and Discussion}

Inputs used per hectare of wheat cultivation in the study area are presented in Table 1 indicates that, the average per hectare utilization of human labour was highest in the case of border strip method of irrigation (78.53 man days/ha) followed by flood method of irrigation (74.15 man days/ha). With respect to bullock labour, the highest consumption was seen in the case of flood irrigation (8.35 pair days/ha) followed by border strip method of irrigation (7.23 pair days/ha). The highest tractor labour was utilized in border strip method of irrigation (6.85 hours/ha) followed by flood method of irrigation (5.43 hours/ha). Most of the farmers in both the methods of irrigation used bullock labour because use of bullock labour worked out to be cheaper than tractor labour use. The study is in conformity with the results of Pavankumar (2011). The average per hectare utilization of seeds was highest in the case of flood method of irrigation $(129.43 \mathrm{~kg} / \mathrm{ha})$ followed by border strip method of irrigation $(129.28 \mathrm{~kg} / \mathrm{ha})$. The average quantity of farmyard manure (FYM) applied per hectare was 


\section{I Macrothink}

Journal of Agricultural Studies

ISSN 2166-0379

2015, Vol. 3, No. 2

highest in the case of border strip method of irrigation (1.08 tonnes/ha) as compared to flood method of irrigation (1.05 tonnes/ha). The fertilizers applied per hectares was highest in case of border strip method of irrigation $(257.18 \mathrm{~kg} / \mathrm{ha})$ followed by flood method of irrigation $(252.16 \mathrm{~kg} / \mathrm{ha})$. Among the different inputs used, the average per hectare utilization of human labour was highest in case of both the methods of irrigation because most of the operations such as harvesting and weeding were human labour intensive. The study is also supported by Pavankumar (2011).

The highest yield was obtained in the case of border strip method of irrigation $(28.50 \mathrm{q} / \mathrm{ha})$ followed by flood method of irrigation ( $20.90 \mathrm{q} / \mathrm{ha}$ ). The average quantity of wheat by product was also highest in the case of border strip method of irrigation $(25.73 \mathrm{q} / \mathrm{ha})$ followed by flood method of irrigation (20.50 q/ha). The study is also supported by the Manasa (2010).

Table 1. Input use pattern and output obtained in Wheat cultivation under different irrigation methods

(Per ha)

\begin{tabular}{|c|l|c|c|c|}
\hline $\begin{array}{r}\text { Sl. } \\
\text { No. }\end{array}$ & \multicolumn{1}{|c|}{ Particulars } & Units & $\begin{array}{c}\text { Flood } \\
(\mathbf{n = 3 5})\end{array}$ & $\begin{array}{c}\text { BSI } \\
(\mathbf{n = 3 5})\end{array}$ \\
\hline 1. & Human labour & Man days & 74.15 & 78.53 \\
\hline 2. & Bullock labour & Pair days & 8.35 & 7.23 \\
\hline 3. & Tractor labour & Hours & 5.43 & 6.85 \\
\hline 4. & Seeds & Kgs & 129.43 & 129.28 \\
\hline 5. & Farm yard manure & Tonnes & 1.05 & 1.08 \\
\hline 6. & Fertilizers & Kgs & 118.72 & 129.16 \\
\hline & Urea & Kgs & 133.44 & 128.02 \\
\hline & DAP & Kgs & - & - \\
\hline & Complex & Kgs & 252.16 & 257.18 \\
\hline & Total & Rs. & 2898.47 & 2051.13 \\
\hline 7 & Cost of Irrigation & Qtls. & 20.90 & 28.50 \\
\hline 8 & Main Product & Qtls & 20.50 & 25.73 \\
\hline 9 & By-product & & & \\
\hline
\end{tabular}

Note: BSI- Border Strip Irrigation

The cost incurred and returns realized from wheat cultivation were calculated and are presented in Table 2. Among the different methods of irrigation, the total variable cost incurred per hectare in border strip method of irrigation was the highest (Rs. 29359.58/ha) followed by flood method of irrigation (Rs. 27842.29/ha) because in border strip method of irrigation the cost of human labour, bullock labour and tractor labour was higher as compared to flood irrigation method.

The distribution pattern of operational cost under various inputs revealed that the cost of human labour was highest in case of border strip method of irrigation (Rs. 12337.98/ha) followed by flood method of irrigation (Rs. 11653.28/ha). This is because in border strip method of irrigation, yield obtained was more than the yield obtained in traditional method 
which required more units of human labour for harvesting and post harvest activities where as bullock labour cost was highest in case of border strip method of irrigation which was Rs. 3075.75/ha followed by flood method of irrigation (Rs. 2803.18/ha). The cost of machine labour was highest in case of border strip method of irrigation (Rs. 4114.28/ha) followed by flood method of irrigation (Rs. 2714.28/ha). The cost of seeds was highest in case of flood method of irrigation (Rs. 1941.43/ha) followed by border strip method of irrigation (Rs. 1907.85/ha). The cost of FYM was highest in the case of border strip method of irrigation (Rs. 439.31/ha) followed by flood method of irrigation (Rs. 427.11/ha) and expenditure on fertilizers applied per hectare in the study area was also highest in case of flood method of irrigation (Rs. 3828.58/ha) followed by border strip method of irrigation (Rs. 3771.43/ha).

The irrigation method wise analysis indicated that the fixed cost incurred per hectare in case of border strip method of irrigation was high (Rs. 8186.53/ha) as compared to flood method of irrigation (Rs. 7952.63/ha). Among the different items of fixed costs, rental value of land was the highest in both the methods. In case of flood method of irrigation it was Rs. 4791.90/ha and in case of border strip method of irrigation it was Rs. 4831.55/ha. The other items like land revenue, depreciation charges and interest on fixed cost are of minor importance.

Among the two methods of irrigation the total cost incurred in the border strip method of irrigation was highest (Rs. 37546.11/ha) as compared to flood method of irrigation (Rs. 35794.91/ha) as the cost of human labour, bullock labour and machine labour was more which ultimately resulted in high cost of cultivation in border strip irrigation method. The gross returns and the net returns were high in case of border strip method of irrigation.

The irrigation method wise analysis of gross returns indicated that the gross returns obtained per hectare in border strip method of irrigation was high (Rs. 58397.12/ha) as compared flood method (Rs. 43819.83/ha). With respect to net returns also, the per hectare net returns obtained in border strip method of irrigation was high (Rs. 20851.01/ha) as compared to flood method (Rs. 8024.92/ha). Thus, cultivation of wheat crop in the study area found to be highly profitable in border strip method of irrigation as also supported by a high magnitude of returns per rupee investment (1.56) as compared to flood method of irrigation (1.22). The study is in conformity with the results of Manasa (2010).

Table 2. Cost and returns structure of Wheat cultivation under different irrigation methods

(Per ha)

\begin{tabular}{|c|c|c|c|c|}
\hline$\frac{\text { Sl. }}{\text { No. }}$ & Particulars & Units & $\begin{array}{l}\text { Flood } \\
(\mathbf{n}=35)\end{array}$ & $\begin{array}{c}\text { BSI } \\
(\mathbf{n}=35)\end{array}$ \\
\hline \multirow{2}{*}{1.} & \multirow{2}{*}{ Human labour } & Rs. & 11653.28 & 12337.98 \\
\hline & & & $(32.56)$ & $(32.86)$ \\
\hline \multirow{2}{*}{2.} & \multirow{2}{*}{ Bullock labour } & Rs. & 2803.18 & 3075.75 \\
\hline & & & $(7.83)$ & $(8.19)$ \\
\hline \multirow{2}{*}{3.} & \multirow{2}{*}{ Tractor labour } & Rs. & 2714.28 & 4114.28 \\
\hline & & & $(7.58)$ & (10.96) \\
\hline
\end{tabular}




\begin{tabular}{|c|c|c|c|c|}
\hline \multirow{2}{*}{4.} & \multirow{2}{*}{ Seeds } & Rs. & 1941.43 & 1907.85 \\
\hline & & & $(5.42)$ & $(5.08)$ \\
\hline \multirow{2}{*}{5.} & \multirow{2}{*}{ Farm yard manure } & Rs. & 427.11 & 439.31 \\
\hline & & & $(1.19)$ & $(1.17)$ \\
\hline \multirow{2}{*}{6.} & \multirow{2}{*}{ Fertilizers } & Rs. & 3828.58 & 3771.43 \\
\hline & & & $(10.70)$ & $(10.04)$ \\
\hline \multirow[t]{2}{*}{8} & Cost of Irrigation & Rs. & 2898.47 & 2051.13 \\
\hline & & & $(8.10)$ & $(5.46)$ \\
\hline \multirow[t]{4}{*}{9} & Interest on working capital & Rs. & 1575.98 & 1661.86 \\
\hline & & & $(4.40)$ & $(4.43)$ \\
\hline & Total variable cost (A) & Rs. & 27842.29 & 29359.58 \\
\hline & & & $(77.78)$ & $(78.20)$ \\
\hline \multirow[t]{2}{*}{10} & Irrigation charge & Rs. & 100 & 100 \\
\hline & & & $(0.28)$ & $(0.27)$ \\
\hline \multirow[t]{2}{*}{11} & Land revenue & Rs. & 30 & 30 \\
\hline & & & $(0.08)$ & $(0.08)$ \\
\hline \multirow[t]{2}{*}{12} & Rental value of land & Rs. & 4791.90 & 4831.55 \\
\hline & & & $(13.39)$ & $(12.87)$ \\
\hline \multirow[t]{2}{*}{13} & Interest on fixed capital & Rs. & 1905.20 & 1966.08 \\
\hline & & & $(5.32)$ & $(5.24)$ \\
\hline \multirow[t]{6}{*}{14} & Depreciation & Rs. & 1125.53 & 1258.90 \\
\hline & & & $(3.14)$ & $(3.35)$ \\
\hline & Total fixed costs $(B)$ & Rs. & 7952.63 & 8186.53 \\
\hline & & & $(22.22)$ & $(21.80)$ \\
\hline & Total cost of cultivation $(A+B)$ & Rs. & 35794.91 & 37546.11 \\
\hline & & & $(100)$ & $(100)$ \\
\hline \multirow{2}{*}{15} & \multirow{2}{*}{ Main Product } & Qtls. & 20.90 & 28.50 \\
\hline & & Rs./q & 1631.43 & 1602.86 \\
\hline \multirow{2}{*}{16} & \multirow{2}{*}{ By-product } & Qtls & 20.50 & 25.73 \\
\hline & & Rs./q & 474.29 & 494.29 \\
\hline 17 & Total Returns & Rs. & 43819.83 & 58397.12 \\
\hline 18 & Net returns & Rs. & 8024.92 & 20851.01 \\
\hline 19 & Returns per rupee investment & & 1.22 & 1.56 \\
\hline
\end{tabular}

Note: A - Total variable costs

B - Total fixed costs

Figures in the parentheses indicate percentage to total

BSI- Border Strip Irrigation

Table 3 indicates that per hectare crop yield was highest in case of border strip method of irrigation $(28.50 \mathrm{q} / \mathrm{ha})$ followed by flood method of irrigation $(20.90 \mathrm{q} / \mathrm{ha})$. The farm income was also found to be highest in case of border strip method of irrigation (Rs. $20851 / \mathrm{ha}$ ) followed by flood method of irrigation (Rs. 8024/ha). The per hectare water applied for the 
crop was lowest in case of border strip method of irrigation (8.41 ha cm) as compared to the flood method of irrigation (12.04 ha cm). The study is also supported by the Manasa (2010), Webber et al (2006), Shirahatti et al (2001) and Enda Antony and Singandhupe (2004).

Table 3. Impact of different irrigation methods on yield, farm income and water savings in wheat

(Per ha)

\begin{tabular}{|c|l|c|c|c|c|c|c|c|c|c|}
\hline \multirow{2}{*}{$\begin{array}{c}\text { Sl. } \\
\text { No }\end{array}$} & Particulars & \multicolumn{3}{|c|}{ Flood method } & \multicolumn{3}{c|}{ BSI } & \multicolumn{3}{c|}{$\begin{array}{c}\text { Per cent change } \\
\text { (Flood \& BSI) }\end{array}$} \\
\cline { 2 - 11 } & Crop & $\begin{array}{c}\text { Yield } \\
\text { (q/ha) }\end{array}$ & $\begin{array}{c}\text { Income } \\
\text { (Rs. /ha) }\end{array}$ & $\begin{array}{c}\text { Wa } \\
\text { (ha } \\
\text { (m) }\end{array}$ & $\begin{array}{c}\text { Yield } \\
\text { (q/ha) }\end{array}$ & $\begin{array}{c}\text { Income } \\
\text { (Rs. } \\
\text { /ha) }\end{array}$ & $\begin{array}{c}\text { Wa } \\
\text { (ha } \\
\text { cm) }\end{array}$ & $\begin{array}{c}\text { Yield } \\
(\%)\end{array}$ & $\begin{array}{c}\text { Income } \\
(\%)\end{array}$ & $\begin{array}{c}\text { Wa } \\
(\%)\end{array}$ \\
\hline 1 & Wheat & 20.90 & 8024 & 12.04 & 28.50 & 20851 & 8.41 & 26.67 & 61.51 & 30.17 \\
\hline
\end{tabular}

Note: Wa: Water applied

BSI: Border Strip Method of Irrigation

\section{Conclusion and Recommendations}

The objective of the intervention in the command area was to ensure better utilization of water available in the canal to grow the crops to improve the productivity and thereby increase the income and standard of living of farm families, who were dependent on the canal irrigation. Therefore, the farmers of the command area could cultivate crops under improved methods of irrigation which will not only save irrigation water, but at the same time generate more remunerative yields and more farm income.

Due to poor canal distribution network structures, owing to inadequate maintenance and repairs, the farmers were facing water shortages, in time and required quantity. Because of the shortage of water and no surety of water supply in time, the farmers were flooding the farms whenever they get water with more quantity of water which results in surface runoff and other soil related problems. Thus, on farm development, adoption of border strip method of irrigation and maintenance of canals needs to be taken up for more efficient use of water. There is necessity to convince the farmers regarding the efficiency of this water saving technology in the command area. It is necessary to give more stress on such aspects during the meeting of canal water users. Water used for irrigation was more in flooding in cultivation of wheat while it was reduced in improved method of irrigation (Border Strip Method of Irrigation), and also there was increase in yield, income and water savings in improved methods. So there is need to impart technical know-how to the farmers of the command area.

\section{References}

Anonymous, (2007). Report of the Steering Committee on Water Resources for Eleventh Five Year Plan (2007-2012), Government of India, Planning Commission

Enda, A., \& Singandhupe, R. B. (2004). Impact of drip and surface irrigation on growth, yield and WUE of capsicum (Capsicum annum L.). J. Agric. Water Mngt., 65, 21-132.

Manasa, P. B. (2010). Water use efficiency in different irrigation methodsin tank commands- 
a management. M. Sc. (Agri.) Thesis, Univ. Agric. Sci., Dharwad, Karnataka (India).

Pavankumar. (2011). Economics of Bt. Cotton cultivation - a comparative analysis across different farm sizes in northern transitional zone, Karnataka. M. Sc. (Agri.) Thesis, Univ. Agric. Sci., Dharwad.

Shirahatti, M. S., Itnal, C. J., \& Mallikarjunappa Gouda, D. S. (2001). Comparison of drip and furrow irrigated cotton on a red soil. Proc. Intl. Conf. on Micro and Sprinkler System, 659-656.

Webber, H. A., Madramootoo, C. A., Bourgault, M., Horst M. G., Stulina, G., \& Smith, D. L. (2006). Water use efficiency of common bean and green gram grown using alternate furrow and deficit irrigation, Agric. Water Mngt., 86(3), 259-268.

\section{Copyright Disclaimer}

Copyright for this article is retained by the author(s), with first publication rights granted to the journal.

This is an open-access article distributed under the terms and conditions of the Creative Commons Attribution license (http://creativecommons.org/licenses/by/3.0/). 